\title{
Evaluasi KinerJa Ruas Jalan Terhadap Perkembangan Kegiatan Perdagangan Dan Jasa Di Ruas Jalan Yosodipuro, KOTA SURAKARTA
}

\author{
Dinda Ismira Setyoningtyas, Kuswanto Nurhadi, Isti Andini \\ Program Studi Perencanaan Wilayah dan Kota, \\ Jurusan Arsitektur, Fakultas Teknik \\ Universitas Sebelas Maret, Surakarta \\ email: dindaismira@yahoo.com
}

\begin{abstract}
Jalan Yosodipuro is a local path that connects the city of Surakarta to downtown. Jalan Yosodipuro is a strategic area close to the main line of Surakarta City, Jalan Slamet Riyadi. The development of economic activity in this streets has began since the construction of a Mall that Solo Paragon Mall. As trade and service area began to grow, commercial activities dominate land use along the road Yosodipuro complement previous activities: education and housing. Means of trade and services in the form of a shop and even the development of the home into a place of business functions are often found along Jalan Yosodipuro. The high activity in this region causes the amount of movement of the vehicle is not able to be accommodated by the existing road capacity.

To overcome this problem researchers conducted a study on the evaluation of the performance of the road to the development of trading activities and services. The analytical method used in this study is the analysis of the development of trade and services activities include the development of the number of business units, floor area, extensive land use and range of activities. Analysis of changes in the performance of roads which include changes in the flow of vehicles, number of occurrences side barriers, and the capacity of the road and analysis croosstab. From the overall results of analysis show that the activity of trade and services in the Yosodipuro Road experienced growth from 2010 - 2014. The development of trade and services activities cause a disturbance in the traffic activity in Yosodipuro Road. From the research that has been conducted found that the development of trade and services activities in road Yosodipuro large influence on changes in the side barrier and the amount of traffic flow, as well as the effect being to change the capacity of the road.
\end{abstract}

Keywords: Degree of Saturation, Levels of Service, Road

\section{PENDAHULUAN}

Kota dapat diartikan sebagai suatu sistem jaringan kehidupan manusia yang ditandai dengan kepadatan penduduk yang tinggi dan diwarnai dengan strata sosialekonomi yang heterogen dan coraknya yang materialistis, atau dapat pula diartikan sebagai bentang budayayang ditimbulkan oleh unsur-unsur alami dan non alami dengan gejala-gejala pemusatan penduduk yang cukup besar dengan corak kehidupan yang bersifat heterogen dan materialistis dibandingkan dengan daerah belakangnya (Bintarto,1983). Kota merupakan tempat untuk bermukimnya warga kota, tempat bekerja, dan tempat rekreasi. Sehingga kelangsungan dan kelestarian kota harus didukung oleh sarana dan prasarana yang memadai untuk waktu yang selama mungkin.

Perkembangan dan perubahan jenis guna lahan memberikan dampak yang besar terhadap penurunan kinerja sebuah ruas jalan. Perubahan-perubahan fungsi dan luas jenis guna lahan menjadi sebab munculnya gangguan samping yang ditimbulkan dari kegiatannya (Sijabat,2007). Salah satu jenis tata guna lahan yang memiliki pengaruh cukup besar terhadap pergerakan lalu lintas adalah perdagangan (Z.Tamin, 1997). Fasilitas perdagangan yang terwujud dalam bentuk pasar tradisional, pasar modern, dan 
pertokoan merupakan salah satu jenis tata guna lahan yang menarik maupun membangkitkan perjalanan dalam jumlah signifikan. Adanya bangkitan dan tarikan perjalanan oleh tata guna lahan perdagangan tersebut membutuhkan dukungan kinerja sarana dan prasarana transportasi, berupa angkutan umum, ruas dan simpang jalan, areal perparkiran, fasilitas pejalan kaki, halte, terminal dan sebagainya. Tanpa adanya dukungan sarana dan prasarana transportasi, dipastikan akan terjadi ketidakseimbangan antara permintaan dan penawaran perjalanan, yang pada akhirnya akan menimbulkan berbagai permasalahan lalu lintas seperti kemacetan, kesemrawutan dan rendahnya tingkat keselamatan lalu lintas.

Kondisi tersebut terjadi di Ruas Jalan Yosodipuro merupakan kawasan yang strategis dekat dengan jalur utama Kota Surakarta yaitu Jalan Slamet Riyadi. Di ruas jalan ini dulunya didominasi oleh kegiatan permukiman dan pendidikan. Namun semakin berkembangnya kota Surakarta dalam sektor perdagangan dan jasa membuka peluang investasi dari dalam dan luar negeri, sehingga perkembangan kegiatan perdagangan dan jasa seperti pembangunan Mall dan pertokoan juga terjadi di Jalan Yosodipuro. Berdirinya Solo Paragon di ruas Jalan Yosodipuro pada tahun 2010, memberikan dampak yang signifikan terhadap perubahan volume kendaraan di ruas Jalan Yosodipuro karena telah mempengaruhi fungsi lahan yang ada di sekitarnya. Terdapat pergeseran penggunaan fungsi lahan yang sebelumnya merupakan permukiman menjadi bangunan komersial yang ikut menyumbangkan pertambahan volume jalan yag harus ditampung akibat adanya kegiatan-kegiatan perdagangan dan jasa yang berkembang.

Tingginya kegiatan di kawasan ini menyebabkan jumlah pergerakan kendaraan tidak mampu ditampung oleh kapasitas jalan yang ada. Semakin banyaknya intensitas kendaraan lambat yang melintas, kegiatan parkir di pinggir jalan, kegiatan kendaraan keluar masuk yang cukup tinggi dan berakhir pada kemacetan lalu lintas pada jam-jam sibuk, sehingga dapat di katakan bahwa ruas jalan ini memiliki kegiatan yang cukup padat yang berpengaruh terhadap kinerja ruas jalan tersebut.

Tujuan dari penelitian ini adalah mengevaluasi kinerja ruas jalan yang terpengaruh oleh perkembangan kegiatan perdagangan dan jasa di Jalan Yosodipuro.

\section{METODE}

\subsection{Ruang Lingkup}

Ruang lingkup wilayah penelitian adalah di ruas Jalan Yosodipuro dimulai dari pertigaan trafficlight lapangan kota barat hingga bundaran Monumen Pers.

Alasan diambilnya delineasi tersebut adalah karena wilayah tersebut terkena pengaruh dari adanya Pembangunan Solo Paragon Mall dilihat dari sebaran area pertokoan di sepanjang Jalan Yosodipuro tersebut. Selain itu, Jalan Yosodipuro berada di pusat kota yang secara otomatis perkembangannya lebih cepat dan menurut kebijakan RDTR Kota Surakarta, kawasan penelitian ini berada pada BWK VI yang peruntukan utamanya adalah perdagangan dan jasa berupa pertokoan, hotel, dan perkantoran.

Dengan lingkup kajian penelitian berada di ruas Jalan Yosodipuro Kota Surakarta. Untuk memudahkan proses penelitian, Peneliti membagi ruas Jalan Yosodipuro menjadi 3 segmen. Segmen Kawasan I merupakan Jalan Yosodipuro yang dibatasi oleh pertigaan lapangan kota barat hingga perempatan Solo Paragon Mall. Sedangkan untuk segmen II berada di perempatan Solo Paragon Mall hingga perempatan SMA Muhammadiyah 2. Segmen III merupakan bagian Jalan Yosodipuro dari perempatan SMU Muhammadiyah 2 hingga bundaran Monumen Pers.

\subsection{Metode Analisis}

Penelitian ini menggunakan metode penelitian deskriptif kuantitatif. Berikut teknik analisis yang digunakan dalam penelitian ini :

a. Analisis perkembangan kegiatan perdagangan dan jasa. Analisis dengan melakukan perhitungan kuantitatif dan deskiripsi atas besaran peningkatan aspek-aspek penentu kegiatan 
perkembangan perdagangan dan jasa, yaitu jumlah unit usaha, luas lantai, luas penggunaan lahan, jangkauan pelayanan. Analisis dilakukan dengan menghitung besaran perkembangan dengan rumus :

$$
\mathrm{p}=\frac{\mathrm{y}-\mathrm{x}}{\mathrm{x}} \cdot 100 \%
$$

di mana:

$\mathrm{p}=$ prosentase peningkatan; $\mathrm{y}=$ nilai pada tahun akhir; $x=$ nilai pada tahun awal

b. Analisis Perubahan Kinerja Ruas Jalan Analisa MKJI yang digunakan dalam penelitian ini adalah untuk menentukan kapasitas segmen jalan. Untuk mengetahui kinerja ruas Jalan Yosodipuro, dilakukan 3 bentuk analisis, yaitu :

1) Identifikasi jumlah arus lalu lintas Perhitungan arus lalu lintas dilakukan dengan cara menghitung langsung jumlah kendaraan yang melewati ruas Jalan Yosodipuro pada titik-titik yang telah ditentukan setiap hari dalam satu minggu, untuk menentukan hari terpadat dan jam puncak kendaraan. Jenis kendaraan digolongkan menjadi tiga jenis yaitu kendaraan ringan (LV), kendaraan berat (HV), sepeda motor (MC).

2) Identifikasi hambatan samping

Perhitungan jumlah kejadian hambatan samping dilakukan dengan cara menghitung langsung pada titik-titik yang telah ditentukan pada masing-masing segmen di hari terpadat pada jam puncak kendaraan. Jenis hambatan samping digolongkan menjadi empat jenis yaitu kegiatan pejalan kaki (PED), kendaraan parkir (PSV), kendaraan lambat (MV), dan kendaraan masuk dan keluar (EEV).

3) Identifikasi Kapasitas Jalan Yosodipuro

Langkah mencari nilai Kapasitas (C),dengan rumus sebagai berikut :

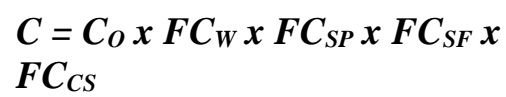

Dimana :

$\mathrm{C}=$ Kapasitas ( smp/jam )

$\mathrm{C}_{\mathrm{O}}=$ Kapasitas dasar untuk kondisi tertentu ( smp/jam )

$\mathrm{FC}_{\mathrm{W}}=$ Faktor penyesuaian lebar jalur lalu lintas

$\mathrm{FC}_{\mathrm{SP}}=$ Faktor penyesuaian pemisah arah

$\mathrm{FC}_{\mathrm{SF}}=$ Faktor penyesuaian hambatan samping

$\mathrm{FC}_{\mathrm{CS}}=$ Faktor penyesuaian ukuran kota

Adapun untuk mencari nilai DS tersebut digunakan rumus berikut ini :

$$
\mathrm{DS}=\mathbf{Q} / \mathbf{C}
$$

Dimana :

DS = Derajat Kejenuhan

$\mathrm{Q}=$ Arus Kendaraan

Kategori nilai derajat kejenuhan

- Nilai DS kurang dari 0,75 maka jalanan tersebut masih dikatakan normal atau tidak macet.

- Nilai DS lebih besar sama dengan 0,75 maka dapat dikatakan bahwa jalan tersebut mulai mengalami kemacetan

c. Analisis Evaluasi Kinerja Jalan terhadap Perkembangan kegiatan perdagangan-jasa

Analisis terakhir yang digunakan untuk menjawab penelitian ini adalah analisis crosstab dari variabel perkembangan kegiatan perdagangan dan jasa terhadap masing-masing variabel kinerja jalan. Untuk dapat melakukan analisis terakhir ini, maka dibutuhkan input data yang berasal dari hasil dua analisis sebelumnya yaitu analisis perkembangan kegiatan perdagangan dan jasa dan perubahan kinerja jalan.

\section{HASIL DAN PEMBAHASAN \\ 3.1 Perkembangan kegiatan perdagangan dan jasa}


a. Perkembangan Jumlah Unit Usaha

Perdagangan dan Jasa

Selama kurun waktu 2010

hingga 2014 terjadi peningkatan jumlah kegiatan perdagangan dan jasa yang cukup signifikan dikawasan ini. Dari hasil observasi lapangan (lihat Lampiran 1. perkembangan Jumlah Unit Usaha Perdagangan dan Jasa) diketahui bahwa perkembangan aktivitas perdagangan dan jasa di koridor ruas jalan Yosodipuro mengalami pertambahan dimana pada tahun 2010 jumlahnya adalah 57 unit usaha dan pada tahun 2014 mengalami kenaikan sebesar 47,4 \% menjadi 84 unit usaha. Dari hasil wawancara yang dihimpun, kecenderungan peningkatan jumlah unit usaha terjadi pada tahun 2011 hingga tahun 2013, dimana pada rentang tahun tersebut mulai tumbuh unit-unit usaha baru di ruas jalan Yosodipuro seperti Ny. Kamto dan Klinik LBC yang terletak di segmen II yang memang sudah memiliki pasar tersendiri. Peningkatan jumlah unit usaha yang paling tinggi terjadi pada segmen II yaitu sebesar 72,2\%. Di segmen II ini jenis usaha yang tumbuh beragam, mulai dari usaha rumahan seperti warung makan dan laundry, klinik kecantikan, praktek dokter, tempat pelatihan mengemudi, jasa perbaikan kendaraan, jasa cuci mobil, restoran, hingga toko pakaian. Aktivitas yangg beragam ini memicu tumbuhnya usaha-usaha baru untuk melengkapi jenis-jenis aktivitas yang sudah ada. Ditambah lagi adanya bangunan ruko pada segmen ini sehingga menambah jumlah unit usaha karena dalam setiap ruko tidak hanya ditempati oleh satu unit usaha. Dan tak tanggung-tanggung kini sudah dibangun dua buah bangunan ruko yang siap untuk ditempati.

b. Perkembangan Luas Lantai Kegiatan Kegiatan Perdagangan dan Jasa

Semakin berkembangnya kegiatan perdagangan dan jasa di koridor ruas Jalan Yosodipuro juga mulai tumbuh bangunan tinggi yang berlantai banyak. Berbeda dengan waktu awal munculnya Solo Paragon Mall tahun 2010, satu-satunya bangunan tinggi yang memiliki lantai banyak hanyalah bangunan Solo Paragon Mall. Namun kini hampir di setiap segmen terdapat bangunan ruko 3 lantai dan yang paling bayak terdapat bangunan ruko ada di segmen II. Dari hasil observasi lapangan (lihat Lampiran 2. Perkembangan Luas Lantai Kegiatan Industri dan perdagangan jasa) diketahui bahwa perkembangan aktivitas perdagangan dan jasa yang dilihat dari besarnya perkembangan luas lantai aktivitas menunjukkan perkembangan yang sedang di koridor ruas jalan Yosodipuro. Dan apabila dilihat per segmen, segmen II merupakan segmen yang terdapat perkembangan luas lantai kegiatan yang paling tinggi yaitu mencapai $111 \%$. Di segmen II ini memang aktivitas perkantoran seperti jasa asuransi dan jasa keuangan cukup banyak, sehingga luas lantai kegiatannya pun cukup besar dibandingkan dua segmen yang lain.

c. Perkembangan Luas Penggunaan Lahan Kegiatan Perdagangan dan Jasa

Dari hasil observasi lapangan (lihat Lampiran 3. Perkembangan Penggunaan Lahan Perdagangan dan Jasa) secara keseluruhan di koridor ruas jalan Yosodipuro rendah yaitu sebesar $14,11 \%$. Namun apabila dilihat per segmen, dari hasil perhitungan menunjukkan perkembangan sangat besar terjadi dalam waktu lima tahun ini adalah pada segmen II yaitu sebesar $114 \%$. Ini ditandai dengan adanya perubahan pemanfaatan lahan di segmen II menjadi perdagangan dan jasa serta kawasan permukiman dan pendidikan yang ada di segmen II menjadi daya tarik tersendiri bagi masyarakat untuk memanfaatkan lahan di sekitany menjadi daerah perdagangan dan jasa.

d. Perkembangan Jangkauan Kegiatan Perdagangan dan Jasa

Jangkauan kegiatan dilihat dari seberapa jauh kegiatan tersebut menjangkau area pelayanannya dalam penelitian ini terkait jangkuan kegiatan 
kegiatan perdagangan jasa dilihat dari seberapa jauh asal konsumen/customer yang dilayani. Dari hasil observasi lapangan (lihat Lampiran 4. Perkembangan Jangkauan Kegiatan Perdagangan dan Jasa) diketahui perkembangan jangkauan aktivitas keseluruhan di ruas Jalan Yosodipuro sebesar 14,28\% yang berarti termasuk dalam klasifikasi perkembangan rendah. Hal ini disebabkan karena secara rata-rata pertumbuhan aktivitas perdagangan dan jasa yang baru tidak jauh berbeda dengan aktivitas perdagangan dan jasa yang sudah ada sebelumnya sehingga jangkauan aktivitasnya tidak berubah.

\subsection{Perubahan Kinerja Ruas Jalan Yosodipuro}

Survei perhitungan arus lalu lintas dilakukan dengan cara menghitung langsung jumlah kendaraan yang melewati ruas Jalan Yosodipuro pada titik-titik yang telah ditentukan setiap hari dalam satu minggu. Dan untuk mempermudah perhitungan volume lalu lintas, jenis kendaraan digolongkan menjadi tiga jenis yaitu kendaraan ringan (LV), kendaraan berat (HV), sepeda motor (MC). Berikut tersaji dalam tabel jumlah arus lalu lintas, yang merupakan hasil dari pengamatan selama satu minggu. Menurut pengamatan di lapangan (lihat Lampiran 5. Jumlah Arus Lalu Lintas) hari yang tersibuk adalah hari Senin, sejalan dengan kondisi penggunaan lahan di koridor ruas Jalan Yosodipuro yang didominasi oleh kegiatan perdagangan dan jasa, pendidikan, dan perkantoran, maka intensitas pergerakkan pada saat weekdays cukup tinggi. Pada hari selasa hingga Minggu terjadi perubahan volume kendaraan yang fluktuatif. Dan dari hasil traffic counting jumlah arus lalu lintas yang melewati ruas Jalan Yosodipuro pada hari Senin, memiliki jam puncak yaitu pukul 14.00-15.00 WIB yaitu sebesar 3.037 kendaraan/ jam. a. Kejadian Hambatan Samping

'Dari hasil perhitungan dan pengamatan dilapangan, rata-rata kejadian hambatan samping tertinggi di semua segmen terjadi pada waktu siang hari, yaitu yang mencapai kelas medium. Nilai hambatan samping pada siang hari yang paling tinggi berada pada segmen I. Hal ini disebabkan pada segmen I terdapat suatu Mall besar yaitu Solo Paragon Mall, sehingga banyak kegiatan seperti kendaraan berhenti, angkutan umum yang berhenti, orang menyeberang dan orang berjalan kaki yang terjadi secara menerus. Kemudian nilai hambatan samping pada siang hari tertinggi kedua adalah pada segmen II kemudian diikuti segmen III. Pada segmen II dan III ini memiliki kemiripan kondisi ruas jalan, dimana pada segmen II dan III yang menyumbang nilai hambatan samping adalah dari kegiatan perkantoran dan pendidikan yang mendominasi di segmen ini.

b. Kapasitas Jalan Yosodipuro

Untuk menganalisis kapasitas jalan di sepanjang ruas Jalan Yosodipuro ini dengan jumlah penduduk kota Surakarta sebanyak 557.251 jiwa, lebar jalan efektif 6 meter. Hasil Perhitungan Kapasitas Jalan terdapat pada Lampiran 6 . Kapasitas Jalan Yosodipuro pada saat jam puncak

c. Perubahan Kinerja Ruas Jalan

Seiring dengan peningkatan jumlah kegiatan perdagangan dan jasa yang ada maka semakin mengeser area untuk pergerakan kendaraan. Seperti yang dikemukakan Jayadinata (1999) setiap kegiatan ekonomi yang berkembang membutuhkan lahan untuk berkembang. Di ruas Jalan Yosodipuro sendiri perubahan akan kapasitas jalan terus mengalami penurunan, hal ini didukung oleh adanya dorongan peningkatan volume kendaraan sejalan dengan berkembangnya kegiatan perdagangan dan jasa di kanan-kiri ruas Jalan Yosodipuro (lihat Lampiran 7. 
Perubahan Kinerja Jalan ruas Jalan Yosodipuro)

\subsection{Analisis Evaluasi Kinerja Jalan terhadap Perkembangan kegiatan perdagangan-jasa}

Analisis ini berisi tentang sejauh mana perkembangan kegiatan perdagangan dan jasa berpengaruh pada perubahan kinerja ruas Jalan Yosodipuro yang dilihat dari perubahan jumlah hambatan samping, jumlah arus lalu lintas dan kapasitas jalan. Pengaruh perkembangan kegiatan perdagangan dan jasa terhadap arus lalu lintas kendaraan, semakin tinggi tingkat penggunaan sebidang tanah, semakin tinggi pergerakkan arus lalu lintas yang dihasilkan (Z. Tamin, 1997).

Setelah dilakukan penilaian dan pembobotan (lihat Lampiran 8. Crosstab Perkembangan Kegiatan Perdagangan dan jasa terhadap Kapasitas Jalan) didapatkan hasil bahwa pengaruh adanya perkembangan kegiatan perdagangan dan jasa terhadap kinerja jalan yaitu perkembangan kegiatan perdagangan dan jasa berpengaruh besar terhadap perubahan jumlah hambatan samping, berpengaruh besar terhadap perubahan jumlah arus lalu lintas dan berpengaruh sedang terhadap perubahan kapasitas jalan, dan perubahan jumlah arus lalu lintas.

\section{KESIMPULAN}

Secara umum kegiatan perdagangan dan jasa di ruas Jalan Yosodipuro mengalami perkembangan, dilihat dari perkembangan jumlah unit usaha, luas lantai kegiatan, luas penggunaan lahan, dan jangkauan kegiatannya rata-rata perkembangannya adalah rendah yaitu sebesar 30,6\%. Akibat adanya perkembangan kegiatan perdagangan dan jasa tersebut berpengaruh pada perubahan kinerja jalan. Dilihat dari pengaruhnya, kegiatan perdagangan dan jasa berpengaruh besar terhadap perubahan jumlah hambatan samping, berpengaruh besar terhadap perubahan jumlah arus lalu lintas dan berpengaruh sedang terhadap perubahan kapasitas jalan, dan perubahan jumlah arus lalu lintas.
Berikut evaluasi kinerja jalan pada masing-masing segmen :

a. Segmen I

Dengan perkembangan kegiatan perdagangan dan jasa yang rendah yaitu sebesar $13,9 \%$, menimbulkan perubahan kinerja jalan sebesar $0,3 \mathrm{smp} /$ jam atau sebesar 60\% dari tahun 2010. Pada tahun 2014 ini didapatkan bahwa tingkat pelayanan Jalan untuk segmen I ini sebesar $0,9 \mathrm{smp} / \mathrm{jam}$. Hal ini menandakan Kondisi pelayanan kurang baik, kendaraan berjalan dengan banyak hambatan.

Dari empat indikator penilaian perkembangan kegiatan perdagangan dan jasa, pada segmen I yang menyumbang persentase terbesar yaitu peningkatan jangkauan kegiatan. Oleh karenanya, untuk menekan semakin tingginya perubahan kinerja jalan maka perlu dilakukan pembatasan jangkauan kegiatan.

b. Segmen II

Dengan perkembangan kegiatan perdagangan dan jasa yang tinggi yaitu mencapai $77,4 \%$, menimbulkan perubahan kinerja jalan sebesar $0,4 \mathrm{smp} /$ jam atau sebesar 80\% dari tahun 2010. Pada tahun 2014 ini didapatkan bahwa tingkat pelayanan Jalan untuk segmen II ini sebesar 0,9 smp/ jam. Hal ini menandakan Kondisi pelayanan kurang baik, kendaraan berjalan dengan banyak hambatan.

Dari empat indikator penilaian perkembangan kegiatan perdagangan dan jasa, pada segmen II yang menyumbang persentase terbesar yaitu peningkatan luas penggunaan lahan. Dengan tingginya peningkatan luas penggunaan lahan telah menyumbangkan perubahan hambatan samping sebesar 57\%, penurunan kapasitas sebesar $40 \%$, dan peningkatan jumlah arus lalu lintas sebesar $27,5 \%$.

c. Segmen III

Dengan perkembangan kegiatan perdagangan dan jasa yang sedang yaitu sebesar $31,07 \%$, menimbulkan perubahan kinerja jalan sebesar $0,4 \mathrm{smp} / \mathrm{jam}$ atau sebesar 57\% dari tahun 2010. Pada tahun 2014 ini didapatkan bahwa tingkat pelayanan Jalan untuk segmen III ini sebesar 0,7 smp/ jam. Hal ini menandakan 
Kondisi pelayanan baik, kendaraan berjalan lancar dengan sedikit hambatan.

Dari empat indikator penilaian perkembangan kegiatan perdagangan dan jasa, pada segmen III yang menyumbang persentase terbesar yaitu peningkatan jumlah unit usaha. Oleh karenanya, untuk menekan semakin tingginya angka perubahan kinerja jalan maka perlu dilakukan pembatasan jumlah penambahan unit usaha.

\section{REFERENSI}

\section{$\underline{B U K U}$}

Bintarto. 1983.Urbanisasi dam Permasalahannya, Yogyakarta: Galia Indonesia

Jayadinata, Johara. 1999. Tata Guna Tanah dalam Perencanaan Perdesaan perkotaan \& Wilayah. Bandung: ITB

Miro, Fidel. 2004. Perencanaan Transportasi.Jakarta : Erlangga

Sijabat, Jesno. 2007. Kajian Dampak Perubahan Jenis Penggunaan Lahan terhadap Kinerja Ruas Jalan (Studi Kasus Koridor Jalan Arteri Cicaheum- 154 Cibiru). Bandung : Teknik Planologi ITB.

Z. Tamin. Ofyar. 1997. Perencaan dan Permodelan Transportasi. Bandung : ITB

PERATURAN PERUNDANG-UNDANGAN UU RI No 34 tahun 2006 tentang jalan Peraturan Menteri Perhubungan Nomor: Km 14 Tahun 2006 Tentang Manajemen Dan Rekayasa Lalu Lintas Di Jalan UU RI No 22 Tahun 2009 tentang Lalu lintas dan Angkutan Jalan 


\section{LAMPIRAN}

Lampiran 1. Perkembangan Jumlah Unit Usaha Perdagangan dan Jasa

\begin{tabular}{|c|c|c|c|c|c|}
\hline \multirow[b]{2}{*}{ 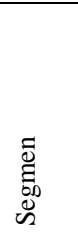 } & \multicolumn{2}{|c|}{ Tahun } & \multirow[b]{2}{*}{ 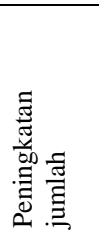 } & \multirow[b]{2}{*}{ 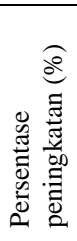 } & \multirow[b]{2}{*}{ 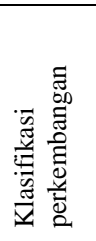 } \\
\hline & 2010 & 2014 & & & \\
\hline I & 18 & 21 & 3 & 16,7 & Rendah \\
\hline II & 18 & 31 & 13 & 72,2 & Tinggi \\
\hline III & 21 & 32 & 11 & 52,3 & Sedang \\
\hline Total & 57 & 84 & 27 & 47,4 & Sedang \\
\hline
\end{tabular}

Sumber : Disperindag Kota Surakarta, Kantor Kelurahan, survey lapangan 2014

Lampiran 2. Perkembangan Luas Lantai Kegiatan Industri dan perdagangan jasa

\begin{tabular}{|c|c|c|c|c|c|}
\hline \multirow[b]{2}{*}{$\begin{array}{l}\text { ల్ } \\
\text { ప్d. } \\
\stackrel{\infty}{n}\end{array}$} & \multicolumn{2}{|c|}{ Tahun } & \multirow[b]{2}{*}{ 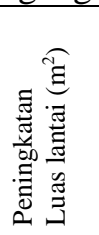 } & \multirow[b]{2}{*}{ 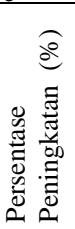 } & \multirow[b]{2}{*}{ 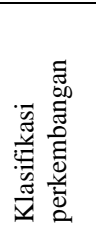 } \\
\hline & 2010 & 2014 & & & \\
\hline I & 183.498 & 185.308 & 1.810 & 0,9 & Rendah \\
\hline II & 2.105 & 4.446 & 2.341 & 111 & Tinggi \\
\hline III & 3.161 & 4.078 & 917 & 29 & Rendah \\
\hline Total & 188.764 & 193.832 & 5.068 & 46,9 & Sedang \\
\hline
\end{tabular}

Sumber: Analisis Peneliti, 2014

Lampiran 3. Perkembangan Penggunaan Lahan Perdagangan dan Jasa

\begin{tabular}{|c|c|c|c|c|c|}
\hline \multirow[b]{2}{*}{ 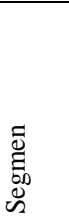 } & \multicolumn{2}{|c|}{ Tahun } & \multirow[b]{2}{*}{ 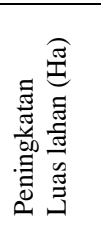 } & \multirow[b]{2}{*}{ 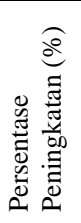 } & \multirow[b]{2}{*}{ 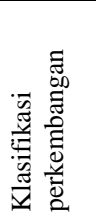 } \\
\hline & 2010 & 2014 & & & \\
\hline I & 4,21 & 4,41 & 0,2 & 4,7 & Rendah \\
\hline II & 0,27 & 0,58 & 0,31 & 114 & Tinggi \\
\hline III & 0,41 & 0,59 & 0,18 & 43 & Sedang \\
\hline Total & 4,89 & 5,58 & 0,69 & 14,1 & Rendah \\
\hline
\end{tabular}

Sumber: Analisi peneliti, 2014 (pengolahan angka menggunakan peta citra 2010, 2014)

Lampiran 4. Perkembangan Jangkauan Kegiatan Perdagangan dan Jasa

\begin{tabular}{|c|c|c|c|c|c|}
\hline \multirow[b]{2}{*}{ 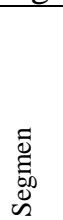 } & \multicolumn{2}{|c|}{ Tahun } & \multirow[b]{2}{*}{ 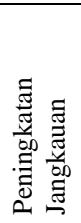 } & \multirow[b]{2}{*}{ 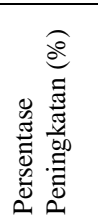 } & \multirow[b]{2}{*}{ 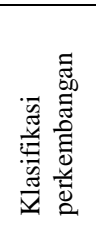 } \\
\hline & 2010 & 2014 & & & \\
\hline I & 0,6 & 0,8 & 0,2 & 33,3 & Rendah \\
\hline II & 0,8 & 0,9 & 0,1 & 12,5 & Rendah \\
\hline III & 0,9 & 0,9 & 0 & 0 & Rendah \\
\hline & 0,7 & 0,8 & 0,1 & 28 & \\
\hline
\end{tabular}

Sumber: Analisi peneliti, 2014
Lampiran 5. Jumlah Arus Lalu Lintas

\begin{tabular}{|c|r|r|r|r|}
\hline \multirow{2}{*}{ Hari } & \multicolumn{3}{|c|}{ Jenis Kendaraan } & \multirow{2}{*}{$\begin{array}{c}\text { Total } \\
\text { (Kend/ } \\
\text { jam) }\end{array}$} \\
\cline { 2 - 4 } & MC & LV & HV & \\
\hline Minggu & 17.971 & 14.654 & 267 & 32.892 \\
\hline Senin & 18.729 & 14.837 & 280 & 33.846 \\
\hline Selasa & 18.987 & 12.065 & 279 & 31.331 \\
\hline Rabu & 16.457 & 13.963 & 236 & 30.656 \\
\hline Kamis & 17.256 & 11.506 & 230 & 28.992 \\
\hline Jumat & 14.269 & 13,434 & 224 & 27.927 \\
\hline Sabtu & 16.471 & 12.804 & 231 & 29.506 \\
\hline $\begin{array}{c}\text { Total } \\
\text { (kend/ } \\
\text { Jam) }\end{array}$ & 171.699 & 109.554 & 2.316 & 296.991 \\
\hline $\begin{array}{c}\text { Rata-rata } \\
\text { Jumlah } \\
\text { kendaraan } \\
\text { (kend/ } \\
\text { jam) }\end{array}$ & 24.529 & 15.651 & 331 & 40.511 \\
\hline
\end{tabular}

Sumber : Pengamatan peneliti, 2014

Lampiran 6. Kapasitas Jalan Yosodipuro pada saat jam puncak

\begin{tabular}{|c|c|c|c|c|c|c|}
\hline 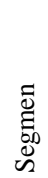 & 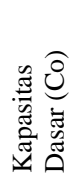 & 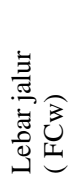 & 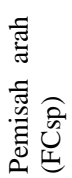 & 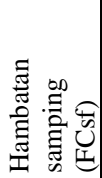 & 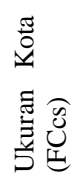 & 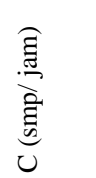 \\
\hline I & 2.900 & 0,87 & 1 & 0,92 & 0,86 & $1.996,2$ \\
\hline II & 2.900 & 0,87 & 1 & 0,92 & 0,86 & $1.996,2$ \\
\hline III & 2.900 & 0,87 & 1 & 0,92 & 0,86 & $1.996,2$ \\
\hline
\end{tabular}

Sumber: Analisi peneliti, 2014

Lampiran 7. Perubahan Kinerja Jalan ruas Jalan Yosodipuro

\begin{tabular}{|c|c|c|c|c|c|c|}
\hline \multirow[b]{2}{*}{ 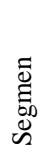 } & \multirow[b]{2}{*}{ 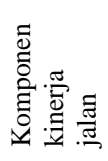 } & \multicolumn{2}{|c|}{ Tahun } & \multirow[b]{2}{*}{ 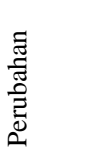 } & \multirow[b]{2}{*}{ 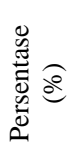 } & \multirow[b]{2}{*}{ 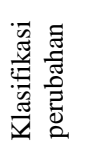 } \\
\hline & & 2010 & 2014 & & & \\
\hline \multirow[t]{3}{*}{ I } & $\mathrm{C}$ & $3.355,1$ & $1.996,2$ & $1.358,9$ & 40 & Sedang \\
\hline & Arus & 1.260 & 1.864 & 604 & 47,9 & Sedang \\
\hline & DS & 0,5 & 0,8 & 0,3 & 60 & Sedang \\
\hline \multirow[t]{3}{*}{ II } & $\mathrm{C}$ & $3.355,1$ & $1.996,2$ & $1.358,9$ & 40 & Sedang \\
\hline & Arus & 1.530 & 1.952 & 422 & 27,5 & Rendah \\
\hline & DS & 0,5 & 0,9 & 0,4 & 80 & Tinggi \\
\hline \multirow[t]{3}{*}{ III } & $\mathrm{C}$ & $3.355,1$ & $1.996,2$ & $1.358,9$ & 40 & Sedang \\
\hline & Arus & 1.530 & 1.717 & 187 & 12,2 & Rendah \\
\hline & DS & 0,3 & 0,7 & 0,4 & 57 & Sedang \\
\hline $\mathrm{T}$ & $\mathrm{C}$ & $3.355,1$ & $1.996,2$ & $1.358,9$ & 40 & Sedang \\
\hline $\mathrm{O}$ & Arus & 1.440 & 1.795 & 355 & 24,6 & Rendah \\
\hline $\begin{array}{l}\mathrm{T} \\
\mathrm{A} \\
\mathrm{L}\end{array}$ & DS & 0,4 & 0,8 & 0,4 & 80 & Tinggi \\
\hline
\end{tabular}

Sumber : Analisa perangkingan ruas jalan Kota Surakarta dan hasil analisis peneliti, 2015 
Lampiran 8. Crosstab Perkembangan

Kegiatan Perdagangan dan jasa terhadap

Kapasitas Jalan

\begin{tabular}{|c|c|c|c|c|c|}
\hline & & \multicolumn{4}{|c|}{$\begin{array}{c}\text { Variabel perkembangan Kegiatan } \\
\text { Perdagangan dan Jasa }\end{array}$} \\
\hline & & $\begin{array}{l}\text { Jumlah } \\
\text { Unit } \\
\text { Usaha }\end{array}$ & $\begin{array}{l}\text { Luas } \\
\text { Lantai } \\
\text { Kegiatan }\end{array}$ & $\begin{array}{l}\text { Luas } \\
\text { Guna } \\
\text { Lahan } \\
\end{array}$ & $\begin{array}{l}\text { Jangkauan } \\
\text { Kegiatan }\end{array}$ \\
\hline & Nilai & sedang & sedang & rendah & rendah \\
\hline $\begin{array}{l}\text { Hambatan } \\
\text { Samping }\end{array}$ & Sedang & $\begin{array}{l}\text { Pengaruh } \\
\text { Besar }\end{array}$ & $\begin{array}{l}\text { Pengaruh } \\
\text { Besar }\end{array}$ & $\begin{array}{l}\text { Pengaruh } \\
\text { sedang }\end{array}$ & $\begin{array}{l}\text { Pengaruh } \\
\text { sedang }\end{array}$ \\
\hline $\begin{array}{l}\text { Jumlah } \\
\text { Arus Lalu } \\
\text { Lintas }\end{array}$ & Rendah & $\begin{array}{l}\text { Pengaruh } \\
\text { Kecil }\end{array}$ & $\begin{array}{l}\text { Pengaruh } \\
\text { Kecil }\end{array}$ & $\begin{array}{l}\text { Pengaruh } \\
\text { Besar }\end{array}$ & $\begin{array}{l}\text { Pengaruh } \\
\text { Besar }\end{array}$ \\
\hline Kapasitas & Sedang & $\begin{array}{l}\text { Pengaruh } \\
\text { Besar }\end{array}$ & $\begin{array}{l}\text { Pengaruh } \\
\text { Besar }\end{array}$ & $\begin{array}{l}\text { Pengaruh } \\
\text { Sedang }\end{array}$ & $\begin{array}{l}\text { Pengaruh } \\
\text { Sedang }\end{array}$ \\
\hline
\end{tabular}

Sumber: Analisi peneliti, 2015 